\author{
N.D. Pankratova, Y.A. Perederii \\ Institute for applied system analysis of National Technical University of Ukraine \\ «Igor Sikorsky Kyiv Polytechnic Institute»
}

\title{
TO THE FUNCTIONING OF CYBER-PHYSICAL OBJECTS AS OPEN SYSTEMS UNDER UNCERTAINTY
}

Consideration of cyber-physical systems as open systems is proposed, taking into account the uncertainty conditions and the rapid development of the Internet of Things market. The properties of open systems with active elements as systems capable of resisting entropic tendencies and exhibiting negentropic tendencies, as well as their correspondence to the properties of modern cyber-physical systems, have been studied. An approach to the formation of the architecture of a cyber-physical system as an open system under conditions of uncertainty is proposed.

Key words: cyber-physical system, open system, Internet of things, entropy.

\author{
Н.Д. Панкратова, Ю.А. Передерій \\ Інститут прикладного системного аналізу Національного технічного університету \\ Украӥни «КПІ ім. Ігоря Сікорського»
}

\section{ДО ФУНКЦІОНУВАННЯ КІБЕРФІЗИЧНИХ ОБ'ЄКТІВ ЯК ВІДКРИТИХ СИСТЕМ В УМОВАХ НЕВИЗНАЧЕНОСТІ}

Запропоновано розгляд кіберфізичних систем як відкритих систем, беручи до уваги умови невизначеності та стрімкий розвиток ринку Інтернету речей. Вивчено властивості відкритих систем 3 активними елементами як систем, здатних протистояти ентропійним тенденціям та виявляти негентропійні, а також їх відповідність властивостям сучасних кіберфізичних систем. Запропоновано підхід до формування архітектури кіберфізичної системи як відкритої системи за умов невизначеності.

Ключові слова: кіберфізична система, відкрита система, інтернет речей, ентропія.

\section{Н.Д. Панкратова, Ю.А. Передерий}

Институт прикладного системного анализа Национального технического университета Украинье «КПИ им. Игоря Сикорского»

\section{К ФУНКЦИОНИРОВАНИЮ КИБЕРФИЗИЧЕСКИХ ОБЪЕКТОВ КАК ОТКРЫТЫХ СИСТЕМ В УСЛОВИЯХ НЕОПРЕДЕЛЕННОСТИ}

Предложено рассмотрение киберфизических систем как открытых систем, принимая во внимание условия неопеделенности и стремительное развития рынка Интернета вещей. Изучены свойства открытых систем с активными элементами как систем, способных противостоять энтропийным тенденциям и проявлять негэнтропийные, а также их соответствие свойствам современных киберфизических систем. Предложен подход к формированию архитектуры киберфизической системы как открытой системы в условиях неопределенности.

(C) Pankratova N.D., Perederii Y.A., 2021 
Ключевые слова: киберфизическая система, открытая система, интернет вещей, энтропия.

\section{Introduction}

A cyber-physical system (CPS) is an integrated system of computational and physical elements, where a close connection and coordination between computational and physical resources is ensured, which necessitates the creation of two types of models. On the one hand, these are traditional physical models, and on the other, computational models. Regarding the role of modeling in the development of CFS, Edward A. Lee [1,2] asserts the existence of a difference in the role of models in technology and science, which should induce the use of another class of models, where simplicity and clarity of semantics prevail over accuracy and detail. There are three classes of fundamental constraints on modeling, including chaotic behavior, the inability of computers to numerically process the continuum, and the incompleteness of determinism. Ilge Akkaya [3] demonstrates the use of aspectoriented modeling techniques as a systematic way to separate domains of knowledge and cross-cutting issues within the model. In CPS, computational elements interact with sensors that monitor cyber-physical indicators, and with executive elements that make changes to the cyber-physical environment. CPSs carry out computational procedures in their distributed structure, they include "smart nodes" and make it possible to reconfigure flows in the network depending on conditions. Thus, CPSs are distributed systems with the ability to intelligently process and reconfigure flows through intelligent control [4]. In general, in recent years, CPSs have received a great impetus to development, which is associated with an increase in the number of "smart" devices and sensor networks and their integration into ever larger systems, for example, the Internet of Things (IoT) [5]. Convergence creates conditions for a new phenomenon - the Internet of the future, which includes, in addition to the current Internet of people, the Internet of media content, Internet services and the Internet of things. The Internet of Things will create dynamic networks of billions and trillions of such things communicating with each other. In this way, the digital and physical worlds will be connected, for which applications, services, middleware components and end devices are things.

\section{General characteristics of the problem}

The principles of managing the safety and survivability of physical models of CPS by means of STS differ in the peculiarities of the functioning of technical diagnostics tools. There are means of functional and test diagnostics as standard control systems used to assess the general technical state of an object and the state of individual parts, assemblies, parts with specially organized test sequences. The existing approaches and measures do not allow timely identification and prevention of emergency situations and are mainly aimed at identifying failures. There is a problem of accounting for heterogeneous data received from different sensors, applications, and devices, bringing them into a single format. 
The developed physical model of the functioning of complex technical systems (CTS0 is based on the general problem of multifactor risks, the resource of acceptable risk, predicting the destabilizing dynamics of risk factors, principles, hypotheses, axioms that are directly related to the analysis of emergency situations, accidents, and disasters [6-10]. ensuring the guaranteed survivability and safety of the CPS operation is implemented in the form of an information platform for technical diagnostics. This tool allows you to timely and reliably identify, assess, and predict risk factors and, on this basis, considering feedback, timely eliminate the causes of emergency situations before failures and other undesirable consequences. and continuous on-line assessment of critical parameters of objects allows timely identification and elimination of causes that can potentially lead to disruption of the object's normal operation.

The creation of modern technologies determines new requirements for ensuring the technological and environmental safety of the functioning of the CPS. The rapid development of the Internet of Things market leads, in turn, to an increase in demand for systems capable of processing large amounts of data. There is a need to search for new principles and approaches to assessing the guaranteed functioning of CPS with priority areas of safety and survivability, and, above all, complex technogenic and environmentally hazardous technical systems, based on the methodology of system diagnostics. In addition, it is necessary to consider the heterogeneity and diversity of data from different applications and devices, analyze the results obtained and make decisions in a timely manner.

It is predicted that the active development of technologies of the third and fourth industrial revolutions will change not only industry, transport, and the economy as a whole, but will also radically affect human living conditions [13]. These technologies create a new environment of intellectual space, the management of which requires the development of new approaches, initiate new management problems not only of production processes, but also of all social processes, including culture and education. According to K. Schwab's forecasts, "Many of the innovations are just emerging, but soon the turning point will come when technologies begin to develop, layering and reinforcing each other, representing an interweaving of technologies from the world of physics, biology, and digital realities" $[11, \mathrm{p}$. nine]. It is predicted that technologies can begin to interact independently of a person: unmanned vehicles; artificial intelligence systems that will be able to make their own decisions about adjusting production processes, which will allow to quickly eliminate malfunctions, unforeseen deviations from the course of production processes, etc. Innovative technologies radically change not only the production structure and lead to a new organization of management of enterprises and organizations as a whole but will affect all spheres of human life. It is already realized that technological innovations can have both positive and negative effects, and it is necessary to make decisions on the feasibility of introducing new technologies, considering the usefulness and consequences of their introduction.

Considering that CPS are the driving force behind innovative transformations, many complex problems still need to be solved, for the solution of which it is ad- 
visable to consider the functioning of CPS as open systems under conditions of uncertainty. For this, we introduce a number of definitions and concepts of open systems.

\section{The concept and definitions of an open system}

The concept of an open system was proposed by the Austrian biologist L. von Bertalanffy as the basic concept of the organismic approach he developed to the study of complex biological objects and processes [12,13]. An open system by his concept is understood as a system that constantly exchanges matter (mass), energy, information with the environment, and is in a state of mobile equilibrium. The organismic approach proposed by L. von Bertalanffy and the concept of an open system became the basis of the general theory of systems, which made it possible to obtain a number of useful results for the study of processes in systems of various classes - technical, biological, socio-economic [14].

In open systems, in contrast to closed (isolated from the environment), thermodynamic laws appear that seem paradoxical and contradict the second law of thermodynamics. In accordance with this beginning, the general course of physical events in closed systems occurs in the direction of increasing entropy. At the same time, in open systems in which there is a transfer and transformation of matter, in accordance with the concept of L. von Bertalanffy "... it is quite possible to introduce negentropy", i.e., a decrease in entropy; and "... such systems can maintain their high level and even develop towards an increase in the order of complexity" $[15$, p. 42].

The "second law of thermodynamics" term was proposed by R. Clausius in 1850 and gave the first formulation of this law: "Heat cannot by itself pass from a colder body to a warmer one." In 1865 R. Clausius introduced the term "entropy" (from

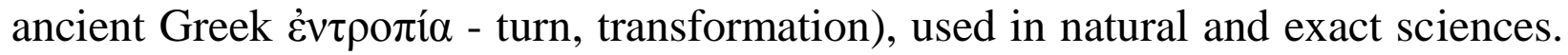
$R$. Clausius introduced entropy as a function of the state of a thermodynamic system, which determines the measure of irreversible energy dissipation. In simple terms, the second law of thermodynamics states that the entropy of a system cannot decrease over time. This means that in nature, things go from a state of order to a state of disorder. And this is irreversible. The system will never become more orderly on its own. The total entropy always increases in a spontaneous process.

One of the main fundamental characteristics of complex systems - the ability to resist entropic (system-destroying) tendencies and exhibit negentropic tendencies in modern systems theory is attributed not to regularities, but to features. However, it can also be viewed as a regularity. It is she who fundamentally distinguishes developing open systems with active elements from closed systems for which the law of physics is valid - the desire of the system to occupy a minimum energy state. According to Bertalanffy, the ability to resist entropic (system-destroying) tendencies and to exhibit negentropic tendencies is due to the openness of the system. But later it was realized that negentropic tendencies are initiated by active elements that stimulate the exchange of material, energy and information products with the environment and show their own "initiatives", an active principle. Due to 
this, in such systems, the regularity of the increase in entropy is violated (analogous to the second law of thermodynamics operating in closed systems, the socalled "second law") and negentropy tendencies are observed, i.e., selforganization itself, development, including "free will" [13]. On the one hand, there is an idea of entropy as chaos, a measure of the disorder of the system, and of negentropy as a measure of order. But, on the other hand, it is negentropic tendencies that are the basis for the development of any innovations, and they destabilize the system, introduce instability, such as disorder. And entropic ones, on the contrary, stabilize the state of the system, since the minimum energy state, to which entropic processes lead, is the most stable.

In contrast to closed systems, under appropriate conditions, an open system reaches $\boldsymbol{a}$ state of mobile equilibrium, in which its structure remains constant. But unlike usual equilibrium, this constancy remains in the process of continuous exchange and movement of matter. The mobile equilibrium of open systems is characterized by the principle of equifinality, that is, "in contrast to the state of equilibrium in closed systems, completely determined by the initial conditions, an open system can reach a time-independent state that does not depend on its initial conditions and is determined solely by the parameters of the system" [13, p.42].

Thus, the concept of an open system in various fields initiated the explanation of evolutionary processes. The approach to living systems as open systems in which nonlinear processes take place has created opportunities for studying the processes of molecular self-organization at the early stages of the emergence of life.

Trying to understand the fundamental possibilities of modeling open and living systems, already the first researchers noted that starting from a certain level of complexity, it is easier to manufacture and put into operation, transform, and change than to formally describe, so that their main feature was realized - the fundamental limitation of the formalized description of developing, self-organizing systems.

Thanks to the law of L. von Bertalanffy, the system exhibits the following abilities:

- the ability to adapt to changing environmental conditions and interferences, both external and internal, not only in relation to interference, but also in relation to control actions;

- the ability to develop options for behavior and change own structure (if necessary);

- the ability to self-organize; (human);

- the ability and desire for goal setting.

Open systems with active elements exhibit the following properties:

- uncertainty, non-stationarity of parameters, instability of the functioning of the system, unpredictability of behavior;

- uniqueness and unpredictability of the system's behavior in specific conditions.

These properties are manifested in the system, due to the presence of active elements in it, as a result of which the system, as it were, manifests "free will", but at the same time there is also the presence of limiting possibilities determined by the 
available resources (elements, their properties) and characteristic a certain type of system structural.

The above features of open systems in the treatment of L. von Bertalanffy confirm the need to consider CPS as open systems.

\section{Formation of the architecture of the CPS as an open system}

The technological basis of CPS is the Internet of Things (IoT), which is the "brain" of the system in the form of technologies for analyzing data received from sensors in the real world. The use of computational models, methods, techniques and their implementation to support the functioning of cyber-physical systems in the parallel world of IoT is given in [17]. The problem of timely informed decision-making to support the functioning of real objects of a specific cyber-physical system in real time is considered.

When considering the use of CPS in various industries, regardless of the domain, at the heart of any of the architectures there are 3 main levels [18-20]:

- device layer is a physical layer that contains sensors for perception and collection of information about the environment, as well as influencing mechanisms;

- gateway level - responsible for transmitting and processing sensor data;

- application layer - the provision of application-specific services.

To solve a specific problem, researchers can extend the architecture of the IoT system in layers, thereby providing security, data storage, data preprocessing, monitoring or control. Considering the peculiarities of the CPS as an open system, it is also important to take into account such properties as the uncertainty and nonstationary parameters, the instability of the functioning of the system, the unpredictability and uniqueness of its behavior in specific conditions. To consider an architecture that can take these factors into account, the proposed architecture is shown in fig. 1.

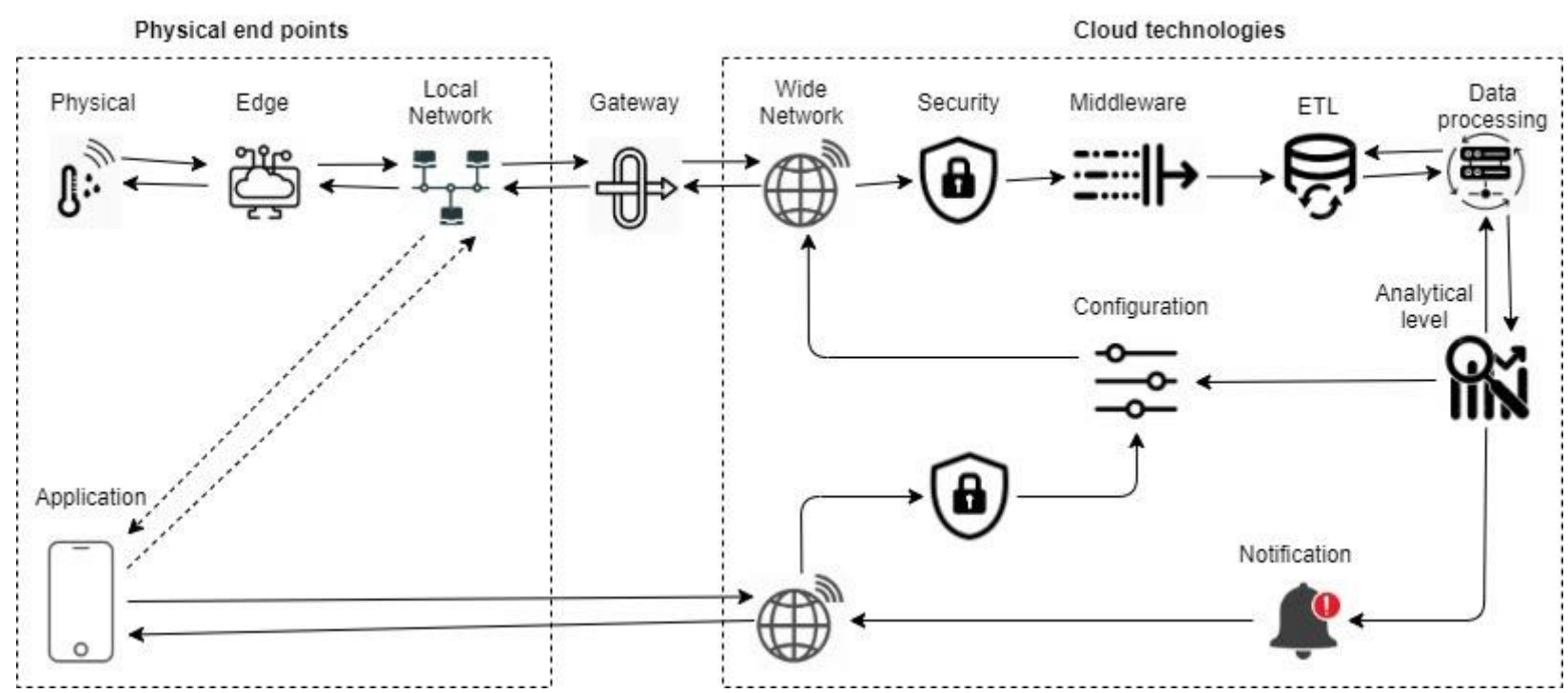

Fig.1. CPS architecture for ensuring the functioning of the system in conditions of uncertainty 
In the same way as an existing IoT architectures, this approach is formed from 3 main components. The purpose of the system elements is as follows:

- Physical Layer represents physical sensors of the FSC and is responsible for collecting information and performing mechanical work.

- Edge Layer converts analog information to digital and / or vice versa and connects to a single sensor or actuator.

- Local Network Layer - covers the task of communication between sensors within the system.

- Gateway Layer - interaction between Physical Endpoints and Cloud Technologies to transfer processed information from peripheral devices to the server and receive configuration data for peripheral devices.

- Wide Network Layer - This layer separates the edge and Cloud Technologies parts of the overall solution, and also includes DNS server-based balancing and location services and many other wireless network components.

- Security Layer provides authentication, authorization and accounting functions, encryption / decryption, along with other services related to connection security.

- Middleware Layer provides back-end functionality for load balancing, message queuing, and streaming.

- ETL layer - data collection and storage layer, information lifecycle management including archiving and destruction.

- Data processing layer is responsible for data preparation and base formation for further analysis.

- Analytic Layer extracts situational information from a complete set of peripherals and predicts future events.

- Notification layer forms the algorithm for notification of events by subscription.

- Configuration Layer - works as a storage for the statuses of peripheral devices.

- Application Layer associated with the M2M stream where information is processed and presented to the customer or support engineer.

Thus, the data obtained from the sensors is transmitted downstream in the proposed CPS architecture to the Analytical layer, in which the methods of system analysis are performed, and solutions are proposed to ensure the guaranteed survivability of the CPS. When creating methods and approaches to data analysis, it is important to consider that this CPS is an open system, which means that the set of properties and behaviors of the system is unlimited and can represent a unique set of events. At the same time, the number of resources for maintaining the survivability of such a system is limited.

\section{Conclusion}

Technological development trends are increasingly faced with the creation of CPS for various innovative solutions. Such solutions must be able to handle a significant amount of data in an open systems environment. Open systems stand out for their ability to self-organize, while CPS, to the extent of its features, should be considered exactly as open systems. The article proposes an approach to building a CPS architecture with such properties, which includes an analytical level for the 
implementation of methods for assessing the guaranteed functioning of a CPS. Also, it allows you to take into account the heterogeneity and diversity of data from various applications and devices, analyze the results obtained and make decisions in a timely manner. The results of the analysis make it possible to judge that it is the approach to CPS as to an open system that will solve many complex existing problems in the evolution of the Internet of Things.

\section{References}

1. Edward A. Lee. Fundamental Limits of Cyber-Physical Systems Modeling. ACM Transactions on Cyber-Physical Systems, 1(1). November, 2016.

2. Edward A. Lee. Modeling in Engineering and Science. Viewpoint, Communications of the ACM 62(1), pp. 35-36, January 2019.

3. Ilge Akkaya, Patricia Derler, Shuhei Emoto, Edward A. Lee. Systems Engineering for Industrial Cyber-Physical Systems using Aspects. IEEE Proceedings. Vol. 104. Issue 5. 4, April, 2016. P. 997-1012.

4. Чеклецов В.В. Идентификация и идентичностьв киберфизическом мире. Философские науки. № 8. 2017. С. 76-86.

5. Черняк Л.. Интернет вещей: новые вызовы и новые технологии. Oткрытые системы. СУБД. № 4. 2013. С. 14-18.

6. Pankratova N., Kurilin B. Conceptual foundations of the system analysis of risks in dynamics of control of complex system safety. Part 2. The general problem of the system analysis of risks and the strategy of its solving. Journal of automation and information. Vol. 33. №4. 2001. P. 1-14.

7. Pankratova N.D. System strategy for guararnteed safety of complex engineering systems. $C y$ bernetics and System Analysis. Vol. 46 (2). 2010. P. 243-251.

8. Pankratova N.D. The integrated system of safety and survivability complex technical objects operation in conditions of uncertainty and multifactor risks. Proceedings of conference IEEE. Kyiv, Ukraine, May 29 - June 2, 2017. N 50. P. 1135-1140.

9. Pankratova N.D., Kondratova L.P. System evaluation of engineering objects' operating taking into account the margin of permissible risk. Eastern-European Journal of Enterprise Technologies. № 3. 2016. P. 13-19.

10. Pankratova, N.D. Creation of Physical Models for Cyber-Physical Systems Lecture Notes in Networks and Systems, 2020, 95, стр. 55-63 Book Chapter DOI: 10.1007/978-3-03034983-7. P. 68-77.

11. Шваб К. Четвертая промышленная революция: перевод с англ. М.: Изд-во «Э», 2017. $208 \mathrm{c}$.

12. Bertalanffy L. von. Vom Sinn und der Einherit der Wissenschaften. «Der Student», Wien. Vol 2. 1947. № $7-8$.

13. Берталанфи Л. фон. Общая теория систем: критический обзор. Исследования по общеей теории систем. М.: Прогресс, 1969. С. 23-82.

14. Волкова В.Н. Открытые системы: Переосмысливая Л. фон Берталанфи. Издательство Политех-пресс, 2019. 440. с.

15. Bertalanffy L. von. General System Theory. «General System». Vol. 1, 1956.

16. Клаузиус Р. Механическая теория тепла. - В кн.: Второе начало термодинамики. М. Л., 1934 Косиманов В.В. Карно, Клапейрон, Клаузиус. М., 1985

17. Pankratova N.D., Ptukha Y.A. Estimation computational models of the cyber-physical systems functioning. System research\&Information technology. №1. 2020. P. 28-33. DOI: https://doi.org/10.20535/SRIT.2308-8893.2020.1.03 
18. Pallavi Sethi, Smruti R. Sarangi Internet of Things: Architectures, Protocols, and Applications. Journal of Electrical and Computer Engineering. Vol. 2017. Article ID 9324035. 25 p. 2017.

19. Burhan et al. (2018) Burhan M, Rehman RA, Khan B, Kim B-S. IoT elements, layered architectures and security issues: a comprehensive survey. Sensors. 2018. 18(9):2796. doi: $10.3390 / \mathrm{s} 18092796$.

20. Yang H., Kim Y. Design and Implementation of High-Availability Architecture for IoTCloud Services. Sensors. 2019;19:3276. doi: 10.3390/s19153276.

Received 15.06. 2021. 